\title{
VHL Gene
}

National Cancer Institute

\section{Source}

National Cancer Institute. VHL Gene. NCI Thesaurus. Code C18261.

This gene is involved in transcriptional repression and protein degradation. 